\title{
Role of endobronchial ultrasound scan in the diagnosis and management of intrapulmonary bronchogenic cyst misdiagnosed by low-dose $\mathrm{CT}$ scan of the chest as lung mass
}

\author{
Ahmed Abdalla, Elfateh Seedahmed, Piyush Patel, Ghassan Bachuwa
}

Hurley Medical Center, Flint, Michigan, USA

\section{Correspondence to}

Dr Ghassan Bachuwa, gbachuw2@hurleymc.com

Accepted 21 December 2016

\section{DESCRIPTION}

A 57-year-old man was referred to the pulmonology clinic for a $3.4 \mathrm{~cm}$ right hilar mass seen in a low-dose CT scan performed for lung cancer screening (figure 1). It was reported as a possible enlarged lymph node or lung mass or vascular abnormality. The patient underwent endobronchial ultrasound scanning, which showed a cystic structure at the right upper lobe and bronchus

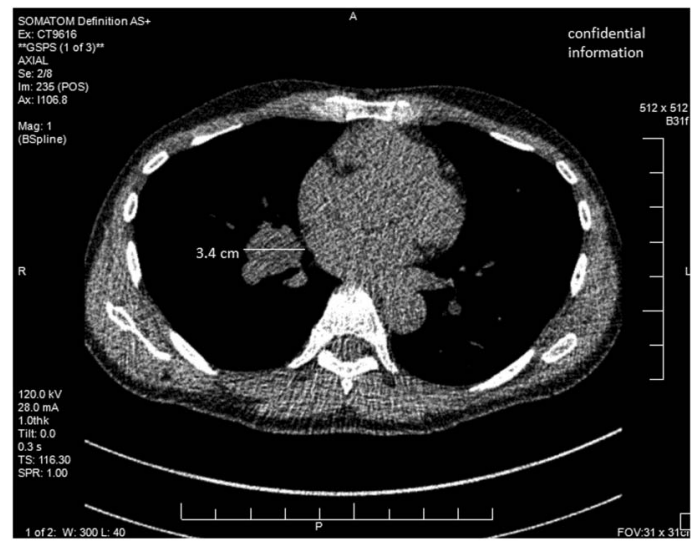

Figure 1 Axial view of low-dose CT of the chest showing $3.4 \mathrm{~cm}$ right hilar density.

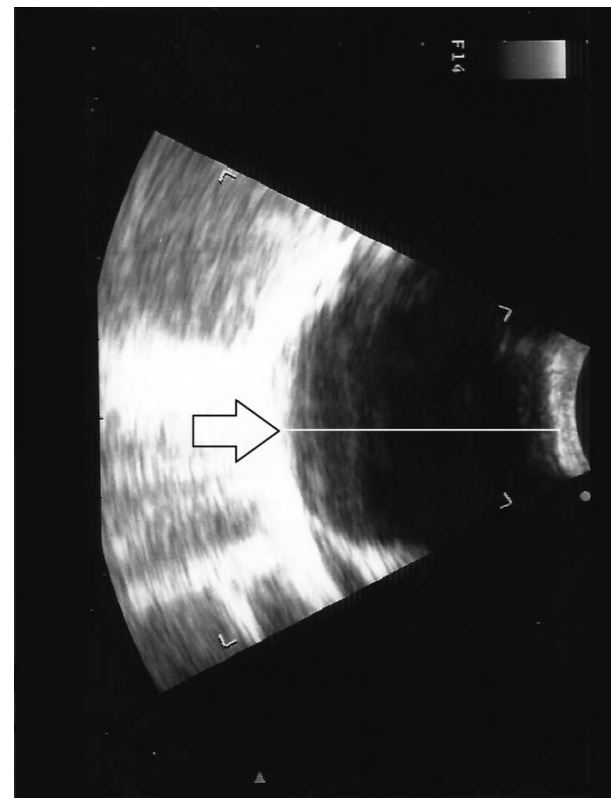

Figure 2 Endobronchial ultrasound scan showing intrapulmonary bronchogenic cyst pre-aspiration.

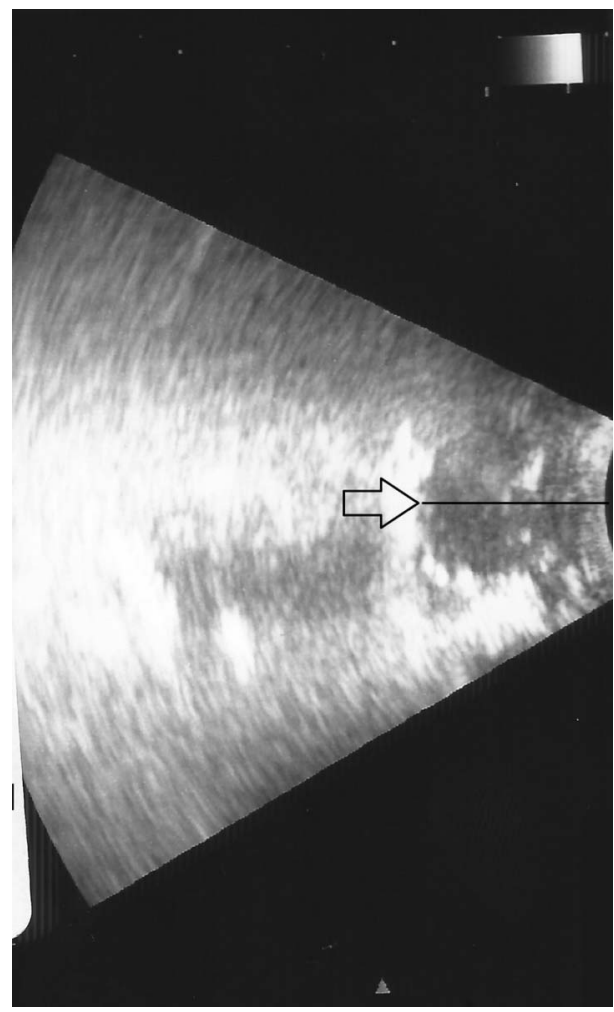

Figure 3 Endobronchial ultrasound scan showing residual debris of the bronchogenic cyst postaspiration.

intermedius bifurcation (figure 2). Endobronchial ultrasound-guided aspiration of the cyst was performed and $14 \mathrm{~mL}$ of clear yellowish fluid was aspirated and sent for cytological examination. The postaspiration image revealed a small cyst with residual debris material (figure 3). The fluid was negative for malignant cells. As the patient remains asymptomatic and has multiple comorbidities, a decision was made for conservative management rather than surgical removal of the residual cyst.

Bronchogenic cyst is a rare congenital lesion derived from primitive foregut. ${ }^{1-3}$ In contrast to our case, most bronchogenic cysts are mediastinal rather than intrapulmonary. ${ }^{1}$

CT scan of the chest usually shows fluid in the cyst with zero density (Hounsfield units), but in some cases density could be higher making the diagnosis more challenging. ${ }^{2} 3$ In our case, fluid density was 20, which favoured other differential diagnosis. Surgical resection of the cyst is the recommended treatment because of the risk of recurrence. $^{3}$ 
The utility of endobronchial ultrasound scan helps with diagnosis of bronchogenic cyst, and obtaining fluid for analysis and possible treatment.

\section{Learning points}

- Low-dose CT has its limitation when it comes to differentiating between solid versus cystic lung lesions. Clinicians and radiologists should be aware of bronchogenic cysts in the differential diagnosis of abnormalities seen during lung cancer screening.

- Endobronchial ultrasound can be used for diagnosing bronchogenic cyst and obtaining a specimen for further evaluation.

- Endobronchial ultrasound scan is more sensitive and specific than low-dose CT in detecting bronchogenic cyst.
Contributors AA planned, designed, wrote and critically revised the manuscript. He prepared the images. He collected data. He had important role to facilitate the work between different authors. He also did the literature review. ES planned, designed and critically revised the manuscript. He played fundamental part to collect data. He helped in processing images. PP planned, designed and critically revised the manuscript. He played fundamental part to collect data. GB planned designed wrote and critically revised the manuscript. He helped in writing learning points.

Competing interests None declared.

Patient consent Obtained.

Provenance and peer review Not commissioned; externally peer reviewed.

\section{REFERENCES}

1 Katsenos S, Rojas-Solano J, Becker HD. Endobronchial ultrasound: a useful tool in the diagnosis of bronchogenic cyst. J Clin Imaging Sci 2013;3:57.

2 Franco-Elizondo R, Patnaik S, Gary Huang K-H et al. Role of endobronchial ultrasound in the diagnosis and management of bronchogenic cysts: two case descriptions and literature review. Southwest J Pulm Crit Care 2014;9:115-122.

3 Maturu VN, Dhooria S, Agarwal R. Efficacy and safety of transbronchial needle aspiration in diagnosis and treatment of mediastinal bronchogenic cysts. J Bronchology Intervent Pulmonol 2015;22:195-203.

Copyright 2017 BMJ Publishing Group. All rights reserved. For permission to reuse any of this content visit

http://group.bmj.com/group/rights-licensing/permissions.

BMJ Case Report Fellows may re-use this article for personal use and teaching without any further permission.

Become a Fellow of BMJ Case Reports today and you can:

- Submit as many cases as you like

- Enjoy fast sympathetic peer review and rapid publication of accepted articles

- Access all the published articles

- Re-use any of the published material for personal use and teaching without further permission

For information on Institutional Fellowships contact consortiasales@bmjgroup.com

Visit casereports.bmj.com for more articles like this and to become a Fellow 